\title{
Foreign Language Anxiety on the Learner of French as a Third Language in Turkey
}

\author{
Recep Gulmez \\ Department of Foreign Languages, Erzincan University, Erzincan, Turkey \\ Email: rgulmez@erzincan.edu.tr
}

\begin{abstract}
The aim of this study is to reveal how anxious Turkish learners of French as a third language become when they study French and the effect of anxiety on learning French. The study was conducted on 84 students (54 male and 30 female) that study in the department of French as a second language. There exist quite many studies on the anxiety especially when it comes to the effect of foreign language learning anxiety on the learners. These studies show that there is a huge amount of foreign language learning anxiety impact on the learners. The present study focuses on the influence of foreign language anxiety on the Turkish learners of French at Ataturk University in Erzurum, Turkey. The results show that the anxiety level is low and the level of achievement in French is quite high as the students already know a cognate language, English they have learned before learning French.
\end{abstract}

Index Terms - language anxiety, French, third language, foreign language learning

\section{INTRODUCTION}

\section{A. French as a Third Language}

In Turkey, French is taught at 23 universities as a foreign language in the department of French as well as in the department of language and literature. Those that study in these departments have knowledge in English before they start to learn French at the university. After they take baccalaureate at the end of high school, they get into these departments at different universities depending on their scores in the exam. As they do learn English from the $4^{\text {th }}$ grade until the end of high school, from a psycholinguistic perspective, these third language learners are experienced learners thanks to Turkish and English learned before. These learners are bilingual and multilingual individuals who present different type of competence as compared to that of monolinguals (Grosjean, 1992; Cook, 1995; Jessner, 1999). Their anxiety level becomes even lower than that of monolinguals. When learners cannot recognize any similarity between the languages, they become more anxious.

The aim of this study is to reveal how effective the language anxiety is on the learner and whether it shows the same extent of effect on bilinguals. Compared to the previous studies on the effect of language learning anxiety on monolinguals, this study aims to explain also the anxiety effect on bilinguals. In our case, the learners that compose the sample of the study have knowledge in a foreign language before they start to learn the second one. Therefore, this paper is to contribute to the researches on foreign language anxiety.

\section{B. Definitions}

It is widely admitted that anxiety can be described as the situation of incentive that happens through physical, sentimental, cognitive changes when one is faced with a motive while foreign language anxiety is defined as the tension and apprehension related to the second language contexts (Gardner \& MacIntyre, 1994). Anxiety is one of the most well-known and controversial concepts in psychology, which is regarded as a negative factor that has to do with feelings like fear, frustration, tension and insecurity (Arnold, 2006). Foreign language anxiety is not a personal characteristic and is not necessarily related to general anxiety (Dewaele, 2006). MacIntyre and Gardner (1989) in their studies have shown that anxiety has a great role in language learning. They imply that the self-confident students do not show foreign language anxiety and in case they do, the level is not too high to prevent them from learning (Brown, 2000). MacIntyre and Gardner (1991a; 1991b) found that students with high levels of French anxiety tended to experience more anxiety when engaged in activities specifically those involving the use of French.

In Turkey, there exists a tendency to regard teaching grammar as the equivalence of teaching language as all the language tests required by public institutions are grammar-based. Demircan (Demircan, 1988) in his study states that grammar though not explicitly explained by the teachers is easy to teach and assess. Horwitz (1986) and others (Horwitz et al., 1986) prove that many are stopped mentally when they learn a foreign language. In this study, we try to find out the role of foreign language anxiety in the learning motivation.

Allwright and Bailey (1991) think that mother tongue has a role in the increase in the level of foreign language anxiety. They also believe that even in their mother tongue courses as in such courses as Turkish history, educational sciences and Turkish as a mother tongue, the students feel the anxiety in foreign language classes. MacIntyre and Gardner (1989) advocate that the students get the feeling of anxiety from bad experiences, misbehaviour and prejudices created against 
that language rather than start to learn foreign language with anxiety. Littlewood (1984) is of the opinion that foreign language is taught in natural environment otherwise this environment turns into the one that makes students feel negative about the language. In the classroom, if they can not pronounce well what they learn, they feel that they are ridiculed by their friends, critized and corrected by their teacher. The language learners that feel diffident and anxious are psychologically introverted for communication in foreign language, which causes the interruption in learning unless this case stops. Indeed, MacIntyre and Gardner (1989) found that French classes were rated as significantly more anxiety-provoking than mathematics or English classes.

MacIntyre (1995) states that anxiety affects listening, learning and comprehension which are second language activities and that students become concerned about miscomprehension or misinterpretation of language rules. Daly (1991) points out that the reason why language learners that feel anxious about language have difficulty in writing is that they get excited when writing just because they feel obliged to strictly obey the rules of proper writing. Öner and Kaymak (1986) state that culture has a great role in anxiety.

It has always become a widely discussed issue how and in what ways language is learned. There exist some factors that affect the way the people learn a second language; social environment, the level of interaction e.t.c which are external factors and language transfer, comprehension e.t.c which are internal (Doğan, 2008). Besides, Freeman and Long (1999) claim that individual differences have a lot of impact on language learning as in other subjects. Individual differences are age, gender, amount of experience in language learning and expressing own mother tongue correctly. Language competence, motivation, behaviour, learning strategies, anxiety, concern and the memory power are regarded as individual differences and affect language learning (Scovel, 1978). Horwitz et.al (1986) point out that the students that have anxiety in foreign language are forgetful and have difficulty in concentration. These students are reported to sweat during the course and deal with their dresses. They are late or never participate in the course, hand in their assignments in time, or be prepared for the course. It is observed that sometimes although they study hard, there is no considerable progress in their situation. Anxiety often brings about some physical symptoms like head-ache, nausea, stress, and inexplicable myalgia.

To put it in a different way, Gardner and MacIntyre stress that the students with anxiety regard learning a second language as a disturbing experience. Therefore, they do not willingly participate in the indoor and outdoor activities and they do think that they will get social pressure when they make mistakes. Many researchers like Horwitz and Cope (1986) believe that foreign language anxiety should be thought separate from that experienced in other courses. Allwright and Bailey (1991) claim that foreign language anxiety should differ from other kinds of anxiety. They explain that foreign language learning process consists of complicated experiences. The process requires the composition of their perceptions, beliefs, emotions and behaviour with classroom but it is not possible to claim it for children. As they are not aware of the rules when they use the language, they are not afraid of making mistakes. So, they easily adapt (Brown, 2000).

The aim of foreign language learning is not to help people acquire different conducts as in learning mother tongue. However, the learners of language find themselves in a different atmosphere in all aspects, which might be a threat to their identity and self-image. Hence, learning a language becomes an element of freight and anxiety rather than excitement. Generally, as second language learning or foreign language acquisition takes place in the class, the students get even more anxious. They feel nervous in this environment just because they think they lack knowledge in the pronunciation and the syntax of the language they learn. If people do not feel at ease in language learning environment, a psychological barrier to language emerges and if the amount of anxiety is more than a certain level, this situation becomes an important obstacle in language learning process (Littlewood, 1984). MacIntyre (1995) states that speaking activities increase the level of anxiety because by speaking the learners of foreign language have to interact with other people. Many researches in this respect have revealed that not only the speaking activities but also other skills like listening, reading and writing can all cause anxiety. Rogers (1989) points out that the reason why students feel anxious about writing in foreign language is that they feel insufficient to do so. Vanc1 (1996) is of the belief that learning a foreign language is an experience that reveals the anxiety for everybody. Kaya (1995) that studies the relation of foreign language learners' motivation, anxiety, self-confidence and therefore their introvert and extravert characters with their participation in classroom activities has revealed that the students having learned a foreign language, highly motivated, self-confident and extravert participate more in the classroom activities than others. It is indicated that the multilingual suffer very little from foreign language anxiety speaking in their first language. But this situation is contrary when one speaks a second language (Dewaele, 2006). Dewaele et al (2008) in his study for example show that foreign language anxiety has a significant negative effect on the recall of French L2 words. An anxious person would not necessarily suffer from anxiety when speaking a foreign language but a generally little anxious multilingual individual may suffer from foreign language anxiety when speaking a second language (Gardner \& MacIntyre, 1994). Another fact is that advanced level learners show similar level of anxiety to that of the beginners (Aida, 1994). Students acknowledge that their anxiety about language results from personal reasons especially when they see speaking and writing skills negative, compare themselves with others and have higher expectations, misbeliefs about language learning. Anxiety results from the students' lack of self-confidence, being compared with others and from theirs views on the language. The discussions and researches on the effect of anxiety on foreign language learning sparkled by Horwitz and Cope (1986) still continue today. They discuss that it becomes more and more important to learn a foreign language nowadays in all areas and those that are aware of the fact are even more anxious. Ganschow and Sparks (1996) studied foreign language anxiety and mother tongue learning competences, the 
effect of the attitudes toward foreign language on women's learning a foreign language. From this study, one can conclude that students' learning their own mother tongue and foreign language competences as well as their positive attitudes and behaviour toward foreign language affect the level of anxiety. The study also shows that the students whose level of anxiety about foreign language is low are more successful in learning a language.

\section{Types of Anxiety}

Several categories of anxiety are in psychology literature. Typically, anxiety as a personality trait is differentiated from a transient anxiety state (Horwitz, 2001). The type of transient anxiety brought on by situations involving threat is called state anxiety (Scovel, 1978) while another type, which is constantly felt by some individuals regardless of threats generated within their environment, is called trait anxiety. State anxiety is considered a normal feeling, whereas trait anxiety is identified as a personality trait that requires therapy and in which some are always anxious oblivious of the environment. Oxford (Oxford, 1999) states students may experience state anxiety in foreign language classes when they are asked to speak, but it diminishes as their foreign language skills and levels of learning increase. Some students develop this type of anxiety into permanent anxiety. Scovel (1978) proposed, based on several researches on the relation between anxiety and achievement, the "facilitating versus debilitating anxiety". Facilitating anxiety leads the learner toward challenging in the new learning environments by adapting approach behaviour while debilitating anxiety results in learner's adaptation of avoidance behaviour. Scovel states that an ordinary individual has both facilitating and debilitating anxiety at the same time and this type of anxiety warns or motivates the individual for any new phenomenon in language learning.

\section{MethoD}

In this study, the sample comprised 84 students whose 54 male and 30 female enrolled in French introductory course. The ages of the participants varied from 17 to 21. Anxiety Scale of French (Annex 1) was used in order to collect data. Before we conducted the scale on the students, we asked them all whether they learned English before they started to learn French. All of the students affirmed the question. The scale was prepared in accordance with 5 Likert type scale response anchors (Strongly disagree, Disagree, Neither agree or disagree, Agree, Strongly agree) for 20 items of 33 on the Foreign Language Classroom Anxiety scale (FLCAS) instrument invented by Horwitz et al. (1986), a 33-item, Likert-type instrument that assesses the degree to which students feel anxious during language class. Horwitz et al. have conducted numerous validity and reliability studies on the instrument. The scale has been shown to be both reliable and valid, with an alpha coefficient of .93 and an eight-week test-retest coefficient of .83 (Horwitz et al., 1986) (Horwitz, 1986) Validity has been established via significant correlations with communication apprehension, as measured by Personal Report of Communication Apprehension, and with test anxiety (McCroskey, 1970). In addition, Aida (1994) reported a Cronbach's alpha coefficient of .94, using a sample of 96 students in a second-year Japanese course. Besides, the study by Ay (2010) was also benefited. Foreign Language Classroom Anxiety Scale whose reliability and validity was measured by Horwitz (2001)is today widely used in foreign language teaching and second language acquisition. As we were given by the department authorities only half an hour to conduct the research, we had to limit the number of items to 20 . To protect the privacy of each student and prevent the impact of one student on the other, we asked the students to sit as separate as possible. SPSS 13.0 was employed for data analysis and the data were analysed by taking into consideration the frequency and percentage of the responses given by the students.

\section{RESUltS}

In this section, the findings obtained through the responses given by the students to the 20 item French Anxiety Scale were studied and interpreted. According to the results obtained through the answers of the students to the items, the following findings can be given. \%41,5 of the students agree (\% 39,2 agree, \% 2,3 strongly agree), \% 42, 8 do not agree (\% 32,1 disagree, \% 10,7 strongly disagree) \%15,4 neither agree nor disagree on the item "I never feel quite sure of myself when I am speaking in French language". From these responses, one can conclude that only a small number of students are confident in speaking French and their level of anxiety is intermediate because a grand proportion (\%42.8) disagrees on the item.

$\% 45,1$ of the students agree ( $\%$ 41, 6 agree, \% 3,5 strongly agree), \%46,3 do not agree (\%38 disagree, \%8,3 strongly disagree), \% 8,3 neither agree nor disagree on the item "I don't worry about making mistakes in French lessons". From these responses, one can conclude that the students have responded in parallel with the answers given above because the proportion of "Agree" and "Disagree" is close and it can be said that the students are partially anxious about making mistakes in French.

$\% 28,4$ of the students agree (\% 26 agree, \%2,3 strongly agree), \% 61,8 do not agree (\% 39,2 disagree, \% 22,6 strongly disagree), \% 9,5 neither agree nor disagree on the item "I tremble when I know that I'm going to be called on in French lessons". From these responses, one can conclude that most of the students are confident in learning a foreign language and do not worry.

$\% 26,2$ of the students agree (\%26 agree, \%2,3 strongly agree), \% 61,9 do not agree (\%50 disagree, \% 11,9 strongly disagree), \%11,9 neither agree nor disagree on the item "It frightens me when I don't understand what my French teacher 
is saying in the foreign language." From these responses, one can conclude that the level of anxiety of the students is lower.

$\% 20$ of the students agree (\%14,2 agree, \%5,9 strongly agree), \%68,9 do not agree (\% 38 disagree, \% 30,9 strongly disagree), \%10 neither agree nor disagree on the item "In French lesson, I find myself thinking about things that have nothing to do with the course." From these responses, one can understand that the students have interest in the course and are highly motivated and also the level of anxiety is lower.

$\% 60,7$ of the students agree (\% 50 agree, \% 10,7 strongly agree), \% 25 do not agree ( $\% 14,8$ disagree, $\% 1,2$ strongly disagree), \% 14,2 neither agree nor disagree on the item "I am usually at ease during tests in French lesson" From these responses, one can see that the students do not worry about French language exams.

$\% 49,9$ of the students agree (\% 39,2 agree, \%10,7 strongly agree), \% 32 do not agree (\% 27,3 disagree, \% 4,7 strongly disagree), \% 17,8 neither agree nor disagree on the item "I start to panic when I have to speak without preparation in French lesson." The results show that when the students are not prepared for the course, the level of their anxiety increases. Besides, it must be considered that the number of those that are indecisive has increased.

$\% 30,9$ of the students agree (\%29,7 agree, \%1,2 strongly agree), \%55,9 do not agree (\%42,8 disagree, \% 13,1 strongly disagree), \%13,1 neither agree nor disagree on the item "In French lesson, I can get so nervous I forget things I know.". From this fact, one can conclude that the students compared to other answers given for the other items trust themselves and the level of their anxiety is lower.

$\% 27,3$ of the students agree (\% 25 agree, \% 2,3 strongly agree), \% 60,6 do not agree (\% 40,4 disagree, \% 20,2 strongly disagree), \%11,9 neither agree nor disagree on the item "It embarrasses me to volunteer answers in French lesson". It can be concluded that most of the students are extremely self-confident and do not worry and some are diffident.

$\% 52,3$ of the students agree (\%35,7 agree, \%16,6 strongly agree), \%34,4 do not agree (\% 29,7 disagree, \% 4,7 strongly disagree), \%13,1 neither agree nor disagree on the item "I would not be nervous speaking French with native speakers." We see that most of the students are confident in speaking French with natives and are never bored. Some students are diffident as seen in the item above.

$\% 38,1$ of the students agree (\% 36,9 agree, \% 1,2 strongly agree), \% 48,8 do not agree (\% 36 disagree, \% 11,9 strongly disagree), \%13,1 neither agree nor disagree on the item "I get upset when I don't understand what my French teacher is correcting." From this fact, we can understand that half of the students are not worried about not understanding what the teacher is correcting and are at ease and some are worried as well as introvert as in the other items.

$\% 40,3$ of the students agree (\%38,1 agree, \%2,3 strongly agree), \% 45,2 do not agree (\% 35,7 disagree, \% 9,5 strongly disagree), \% 14,2 neither agree nor disagree on the item "Even if I am well prepared for French lesson, I feel anxious about it." the responses given show that student are more anxious even though the number of those that disagree is more than the ones that agree. $\% 4,7$ of the students agree ( $\% 4,7$ agree, $\% 0$ strongly agree), \% 86,8 do not agree (\% 45,2 disagree, \% 41,6 strongly disagree), \% 8,3 neither agree nor disagree on the item "I often feel like not going to French lesson." This item confirms that students enjoy taking French course.

$\% 74,9$ of the students agree (\%57,1 agree, \% 17,8 strongly agree), $\% 11,9$ do not agree (\%10,7 disagree, $\% 1,2$ strongly disagree), \%13,1 neither agree nor disagree on the item "I feel confident when I speak in French lesson." These answers show that students in French feel comfortable and are not anxious.

$\% 23,7$ of the students agree (\% 16,6 agree, \% 7,1 strongly agree), \% 72,5 do not agree (\% 51,1 disagree, \% 21,4 strongly disagree), \% 3,5 neither agree nor disagree on the item "The thought that my French teacher is ready to correct every mistake I make frightens me." Therefore, it can be said that most students are not worried about making mistakes.

$\% 17,7$ of the students agree (\%15,4 agree, \% 2,3 strongly agree), \% 67,7 do not agree (\%40,4 disagree, \% 27,3 strongly disagree), \%14,2 neither agree nor disagree on the item "The more I study for a French language test, the more confused I get." The responses show that most students are not worried about studying hard and have seized the importance of study.

$\% 58,3$ of the students agree (\% 47,6 agree, \% 10,7 strongly agree), \% 32 do not agree (\% 26,1 disagree, \% 5,9 strongly disagree), \% 9,5 neither agree nor disagree on the item "I don't feel pressure to prepare very well for language French lesson." The results show that students are content with preparing for French course and are not anxious.

$\% 24,9$ of the students agree (\% 21,4 agree, \% 3,5 strongly agree), \% 60,7 do not agree (\% 48,8 disagree, \% 11,9 strongly disagree), \% 14,2 neither agree nor disagree on the item "I get nervous and confused when I am speaking in French lesson." The results show that most students are quite content with French courses and are not anxious.

$\% 35,7$ of the students agree (\% 25 agree, \% 10,7 strongly agree), \% 51,1 do not agree (\% 41,6 disagree, \% 9,5 strongly disagree), \% 13,1 neither agree nor disagree on the item "I get nervous when I don't understand every word the French teacher says." It is understood that most students are content with French while some are anxious.

$\%$ 47,6 of the students agree (\% 35,7 agree, \% 11,9 strongly agree), \% 40,4 do not agree (\% 32,1 disagree, \% 8,3 strongly disagree), \% 13,1 neither agree nor disagree on the item "I get nervous when French teacher asks questions which I haven't prepared in advance." It is clear from the responses that when students are not ready for the course, their level of anxiety increases.

\section{DiscUSSION}


The results of the study show that the level of foreign language anxiety of students taking French and studying at Ataturk University is low. The principal reason of this fact is the students' achievement in French courses and exams. Another reason is that students master already an Indo-European language which is also cognate to French. It is observed that the level of anxiety of the students is high only when it comes to 7th and 20th items.

$\% 49,9$ of the students agree on the 7 th item "I start to panic when I have to speak without preparation in French lesson."; \% 47,6 of the students agree on the 20th item "I get nervous when French teacher asks questions which I haven't prepared in advance."

Taking into consideration the responses of the students, high level of anxiety is related to the fact that they are not prepared for the course. We suggest that the students should be given some time to get ready for the lessons about which they are informed beforehand in order to make students relaxed. Though some education experts state that this situation will lead students to tend to memorize or cannot be ready to speak spontaneously when they have to do so, they are supposed to inform their students beforehand thinking that the increase in the level of anxiety affects adversely students learning.

In this paper, it was found out that there was negative relation between foreign language anxiety and the students' achievement in French courses. It is indicated that foreign language anxiety is different from ordinary anxiety, proper to the situation, that it emerges in foreign language courses and affects students achievement adversely. It is widely accepted (Onwuegbuzie et al., 1999) that foreign language anxiety has a negative effect on students achievement in foreign language courses.

We can suggest from these findings that those that are to teach French as a foreign language provide a classroom, which is reliable and relaxing for the students because if people do not feel at ease, as seen in Littlewood (1984), they start to have psychological barriers in their mind and if the amount of anxiety is over a certain level, this fact turns into an obstacle in learning process.

Besides, teachers are expected to give students, not being ready for the course, some time to get ready for the lessons about which they are informed beforehand in order to relieve their anxiety and make them relaxed. If teachers did so, they could prevent foreign language anxiety of their students and would facilitate their language learning and help them be away from the environment of anxiety. The learners of French as a third language having knowledge in English start to learn from the 4th grade until the end of high school and feel more relaxed when they see the similarity between both foreign languages. So, it is recommended that the similarities between two cognate languages should be shown and through these similarities make the learners aware of the fact that the language they are learning is not difficult. Dewaele (2007) suggests that quadrilinguals and trilinguals have lower levels of foreign language anxiety in their L2 compared to bilinguals. We suggest that bilingual sources like English-French ones should be consulted during French courses.

TABLE I.

THE ITEMS, FREQUENCY AND PERCENTAGE OF ANSWERS RELATED TO ANXIETY IN FRENCH AS A FOREIGN LANGUAGE

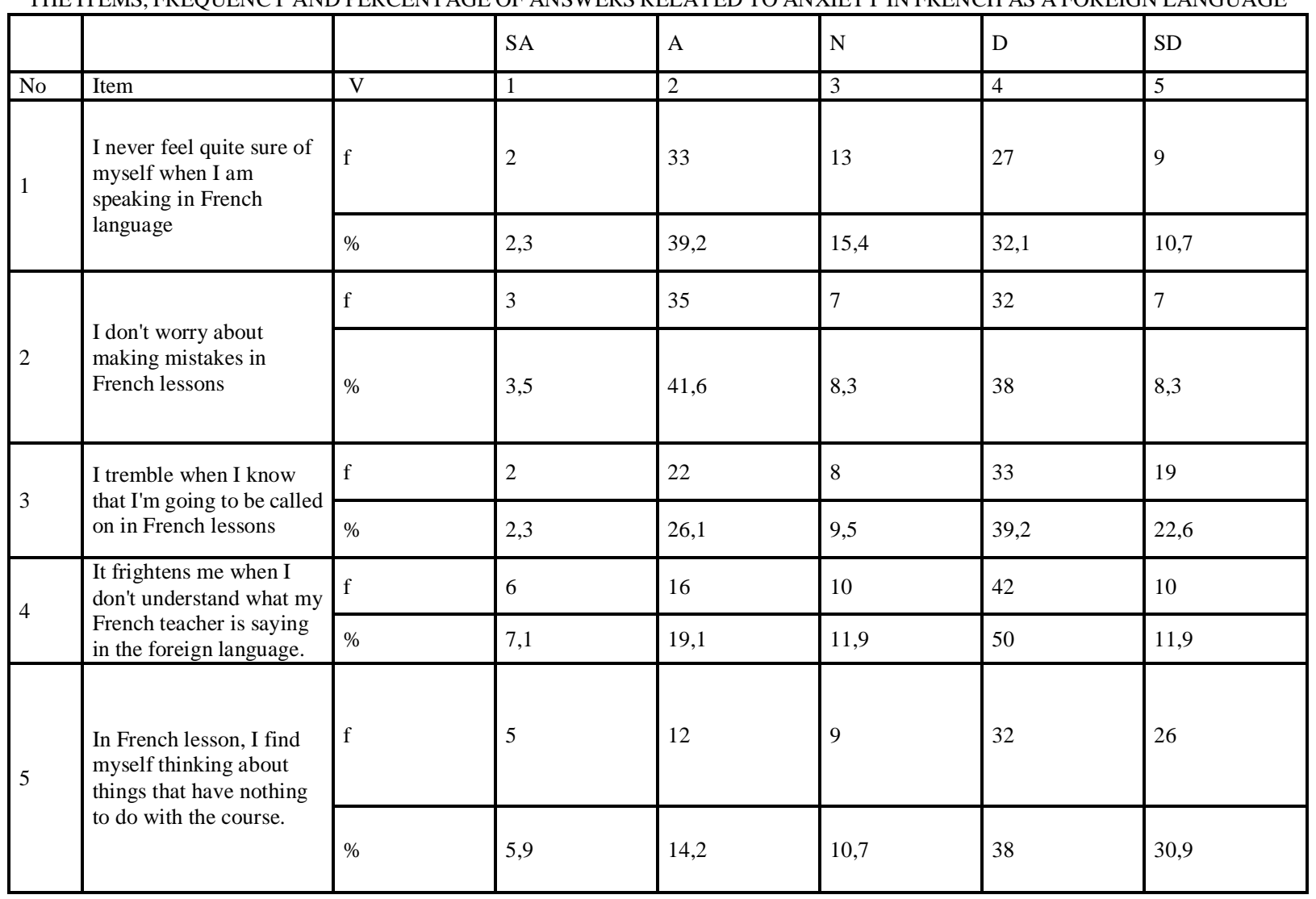




\begin{tabular}{|c|c|c|c|c|c|c|c|}
\hline \multirow{2}{*}{6} & \multirow{2}{*}{$\begin{array}{l}\text { I am usually at ease } \\
\text { during tests in French } \\
\text { lesson }\end{array}$} & $\mathrm{f}$ & 9 & 42 & 12 & 20 & 1 \\
\hline & & $\%$ & 10,7 & 50 & 14,2 & 23,8 & 1,2 \\
\hline \multirow{2}{*}{7} & \multirow{2}{*}{$\begin{array}{l}\text { I start to panic when I } \\
\text { have to speak without } \\
\text { preparation in French } \\
\text { lesson. }\end{array}$} & $\mathrm{f}$ & 9 & 33 & 15 & 23 & 4 \\
\hline & & $\%$ & 10,7 & 39,2 & 17,8 & 27,3 & 4,7 \\
\hline \multirow{2}{*}{8} & \multirow{2}{*}{$\begin{array}{l}\text { In French lesson, I can get } \\
\text { so nervous I forget things } \\
\text { I know. }\end{array}$} & $\mathrm{f}$ & 1 & 25 & 11 & 36 & 11 \\
\hline & & $\%$ & 1,2 & 29,7 & 13,1 & 42,8 & 13,1 \\
\hline \multirow{2}{*}{9} & \multirow{2}{*}{$\begin{array}{l}\text { It embarrasses me to } \\
\text { volunteer answers in } \\
\text { French lesson. }\end{array}$} & $\mathrm{f}$ & 2 & 21 & 10 & 34 & 17 \\
\hline & & $\%$ & 2,3 & 25 & 11,9 & 40,4 & 20,2 \\
\hline \multirow{2}{*}{10} & \multirow{2}{*}{$\begin{array}{l}\text { I would not be nervous } \\
\text { speaking French with } \\
\text { native speakers. }\end{array}$} & $\mathrm{f}$ & 14 & 30 & 11 & 25 & 4 \\
\hline & & $\%$ & 16,6 & 35,7 & 13,1 & 29,7 & 4,7 \\
\hline \multirow{2}{*}{11} & \multirow{2}{*}{$\begin{array}{l}\text { I get upset when I don't } \\
\text { understand what my } \\
\text { French teacher is } \\
\text { correcting. }\end{array}$} & $\mathrm{f}$ & 1 & 31 & 11 & 31 & 10 \\
\hline & & $\%$ & 1,2 & 36,9 & 13,1 & 36,9 & 11,9 \\
\hline \multirow{2}{*}{12} & \multirow{2}{*}{$\begin{array}{l}\text { Even if I am well } \\
\text { prepared for French } \\
\text { lesson, I feel anxious } \\
\text { about it. }\end{array}$} & $\mathrm{f}$ & 2 & 32 & 12 & 30 & 8 \\
\hline & & $\%$ & 2,3 & 38,1 & 14,2 & 35,7 & 9,5 \\
\hline \multirow{2}{*}{13} & \multirow{2}{*}{$\begin{array}{l}\text { I often feel like not going } \\
\text { to French lesson. }\end{array}$} & $\mathrm{f}$ & 0 & 4 & 7 & 38 & 35 \\
\hline & & $\%$ & 0 & 4,7 & 8,3 & 45,2 & 41,6 \\
\hline \multirow{2}{*}{14} & \multirow{2}{*}{$\begin{array}{l}\text { I feel confident when I } \\
\text { speak in French lesson. }\end{array}$} & $\mathrm{f}$ & 15 & 48 & 11 & 9 & 1 \\
\hline & & $\%$ & 17,8 & 57,1 & 13,1 & 10,7 & 1,2 \\
\hline \multirow{2}{*}{15} & \multirow{2}{*}{$\begin{array}{l}\text { The thought that my } \\
\text { French teacher is ready to } \\
\text { correct every mistake I } \\
\text { make frightens me. }\end{array}$} & $\mathrm{f}$ & 6 & 14 & 3 & 43 & 18 \\
\hline & & $\%$ & 7,1 & 16,6 & 3,5 & 51,1 & 21,4 \\
\hline \multirow{2}{*}{16} & \multirow{2}{*}{$\begin{array}{l}\text { The more I study for a } \\
\text { French language test, the } \\
\text { more confused I get. }\end{array}$} & $\mathrm{f}$ & 2 & 13 & 12 & 34 & 23 \\
\hline & & $\%$ & 2,3 & 15,4 & 14,2 & 40,4 & 27,3 \\
\hline \multirow[b]{2}{*}{17} & \multirow{2}{*}{$\begin{array}{l}\text { I don't feel pressure to } \\
\text { prepare very well for } \\
\text { language French lesson. }\end{array}$} & $\mathrm{f}$ & 9 & 40 & 8 & 22 & 5 \\
\hline & & $\%$ & 10,7 & 47,6 & 9,5 & 26,1 & 5,9 \\
\hline
\end{tabular}




\begin{tabular}{|c|c|c|c|c|c|c|c|}
\hline \multirow{2}{*}{18} & \multirow{2}{*}{$\begin{array}{l}\text { I get nervous and } \\
\text { confused when I am } \\
\text { speaking in French } \\
\text { lesson. }\end{array}$} & $\mathrm{f}$ & 3 & 18 & 12 & 41 & 10 \\
\hline & & $\%$ & 3,5 & 21,4 & 14,2 & 48,8 & 11,9 \\
\hline \multirow{2}{*}{19} & \multirow{2}{*}{$\begin{array}{l}\text { I get nervous when I don't } \\
\text { understand every word } \\
\text { the French teacher says. }\end{array}$} & $\mathrm{f}$ & 9 & 21 & 11 & 35 & 8 \\
\hline & & $\%$ & 10,7 & 25 & 13,1 & 41,6 & 9,5 \\
\hline \multirow{2}{*}{20} & \multirow{2}{*}{$\begin{array}{l}\text { I get nervous when } \\
\text { French teacher asks } \\
\text { questions which I haven't } \\
\text { prepared in advance. }\end{array}$} & $\mathrm{f}$ & 10 & 30 & 10 & 27 & 7 \\
\hline & & $\%$ & 11,9 & 35,7 & 11,9 & 32,1 & 8,3 \\
\hline
\end{tabular}

\section{ApPEndix A Foreign (SECOND) LANGUage ClassRoom AnXIETy ScAle}

Directions: Each of the following statements refers to how you feel about your English language class. Please indicate whether you:

- Strongly agree = SA

- Agree = A

- Neither agree nor disagree $=\mathrm{N}$

- Disagree = D

- Strongly disagree $=$ SD

Indicate your feelings by checking the appropriate box next to each statement. Please give your first reaction to each statement. Please mark an answer for EVERY statement.

\begin{tabular}{|c|c|c|c|c|c|}
\hline & SA & A & $\mathrm{N}$ & $\mathrm{D}$ & SD \\
\hline I never feel quite sure of myself when I am speaking in French. & & & & & \\
\hline 2. I don’t worry about making mistakes in French language class. & & & & & \\
\hline 3. I tremble when I know that I'm going to be called on in French language class. & & & & & \\
\hline 4. It frightens me when I don't understand what the teacher is saying in the French language. & & & & & \\
\hline 5. $\quad$ During French language class, I find myself thinking about things that have nothing to do with the course. & & & & & \\
\hline 6. $\quad$ I am usually at ease during tests in French Language Class & & & & & \\
\hline 7. I start to panic when I have to speak without preparation in French lesson. & & & & & \\
\hline 8. $\quad$ In French lesson, I can get so nervous I forget things I know. & & & & & \\
\hline 9. $\quad$ It embarrasses me to volunteer answers in French lesson. & & & & & \\
\hline 10. I would not be nervous speaking French with native speakers. & & & & & \\
\hline 11. I get upset when I don't understand what my French teacher is correcting. & & & & & \\
\hline 12. Even if I am well prepared for French lesson, I feel anxious about it. & & & & & \\
\hline 13. I often feel like not going to French lesson. & & & & & \\
\hline 14. I feel confident when I speak in French lesson. & & & & & \\
\hline 15. I am afraid that my French teacher is ready to correct every mistake I make. & & & & & \\
\hline 16. The more I study for a French language test, the more confused I get. & & & & & \\
\hline 17. I don't feel pressure to prepare very well for French lesson. & & & & & \\
\hline 18. I get nervous and confused when I am speaking in French lesson. & & & & & \\
\hline 19. I get nervous when I don't understand every word the French teacher says. & & & & & \\
\hline 20. I get nervous when French teacher asks questions which I haven't prepared in advance. & & & & & \\
\hline
\end{tabular}

\section{REFERENCES}

[1] Aida, Y. (1994). Examination of Horwitz, Horwitz, and Cope's Construct of Foreign Language Anxiety: The Case of Students of Japanese. The Modern Language Journal, 155-168.

[2] Allwright, D., \& Bailey, K. (1991). Focus on the language classroom: an introduction to classroom research for language. Cambridge: Cambridge University Press.

[3] Arnold, J. (2006). Comment les facteurs affectifs influencent-ils l'apprentissage d'une langue étrangere? Ela. Etudes de linguistique appliquée, 4(144), 407-425.

[4] Ay, S. (2010). Young Adolescent Students' Foreign Language Anxiety in Relation to Language Skills at Different Levels. Journal of International Social Research, 3(11), 83-91.

[5] Brown, H. D. (2000). Principles of Language Learning and Teaching. New York: Pearson Longman.

[6] Cook, V. (1995). Multi-competence and the learning of many languages. Language Culture and Curriculum, 8(2), 93-98. 
[7] Daly, J. (1991). Language Educators. In E. K. Horwitz, \& D. J. Young, Language Anxiety: from theory and research to classroom implications (pp. 3-13). New Jersey: Prentice Hall.

[8] Demircan, Ö. (1988). Dünden Bugüne Türkiye'de Yabancı Dil. İstanbul: Remzi Yayınevi.,

[9] Dewaele, J. M., Petrides, K., \& Furnham, A. (2008). Effects of Trait Emotional Intelligence and Sociobiographical variables pn communicative anxiety and Foreign Language Anxiety among adult multlinguals: A review and Empirical Investigation. Language Learning, 911-960.

[10] Dewaele, J.-M. (2006). L'effet des variables objectives et affectives sur la maitrise orale de multilingues adultes. Ela. Etudes de linguistique appliquée, 4(144), 441-464.

[11] Dewaele, J.-M. (2007). The effect of multilingualism and socio-situational factors on communicative anxiety and foreign language anxiety of mature language learners. The International Journal of Bilingualism, 11(4), 391-410.

[12] Doğan, A. (2008). Lise Öğrencilerinin İngilizce Öğrenimlerini Etkileyen Yabancı Dil Kaygısı. Tömer Dil Dergisi, 48-67.

[13] Freeman, D., \& Long, M. (1999). An Introduction to second language acquisition. Essex: Pearson Longman.

[14] Ganschow, L., \& Sparks, R. (1996). Anxiety about Foreign Language Learning among High School Women. The Modern Language Journal, 80(2), 199-212.

[15] Gardner, R. C., \& Macintyre, P. (1994). The subtle effects of language anxiety on cognitive processing in the second language. Language Learning, 44(2), 283-305.

[16] Grosjean, F. (1992). Another view of Bilingualism. In R. J. Harris, Cognitive Processing in Bilinguals (pp. 51-63). Amsterdam: North Holland.

[17] Horwitz, E. K. (1986). Preliminary evidence for the reliability and validity of a Foreign Language Anxiety Scale. TESOL Quarterly, 559-562.

[18] Horwitz, E. K. (2001). Language Anxiety and Achievement. Annual Review of Applied Linguistics, 21, 112-126.

[19] Horwitz, E. K., Horwitz, M., \& Cope, J. (1986). Foreign Language Classroom Anxiety. The Modern Language Journal, 125-132.

[20] Jessner, U. (1999). Metalinguistic Awareness in multilinguals: Cognitive aspects of third language learning. Language Awareness, 3(4), 201-209.

[21] Kaya, M. (1995). The Relationship of Motivation, Anxiety, Self-Confidence, and Extroversion/Introversion to Students' Active Class Participation in an EFL Classroom in Turkey. Yüksek Lisans Tezi. Ankara: Bilkent Üniversitesi.

[22] Littlewood, W. (1984). Foreign and Second Language Learning. Cambridge: Cambridge University Press.

[23] MacIntyre, P. D. (1995). How does anxiety affect second language learning? A reply to Sparks and Ganschow. Modern Language Journal, 79(1), 90-99.

[24] MacIntyre, P. D., \& Gardner, R. C. (1989). Anxiety and Second-Language Learning: Toward a theoretical clarification. Language Learning, 39(2), 251-274.

[25] MacIntyre, P. D., \& Gardner, R. C. (1991a). Investigating language class anxiety using the focused essay technique. The Modern Language Journal, 75, 296-304.

[26] MacIntyre, P. D., \& Gardner, R. C. (1991b). Language anxiety: Its relation to other anxieties and to processing in native and second languages. Language Learning, 41, 513-534.

[27] McCroskey, J. (1970). Measures of communication-bound anxiety. Speech Monographs, 269-277.

[28] Onwuegbuzie, A. J., Bailey, P., \& Daley, C. E. (1999). Factors associated with foreign language anxiety. Applied Psycholinguistics, 20(2), 217-239.

[29] Oxford, R. (1999). Anxiety and Language Learner: New Insights. In J. Arnold, Affect in Language Learning (pp. 58-67). New York: Cambridge University Press.

[30] Öner, N., \& Kaymak, D. (1986). The Transliteral Equivalence and the Reliability of the Turkish TAI. In R. Schwarzer, H. V. Ploeg, \& C. Spielberger, Advances in Test Anxiety Research (pp. 227-239). New Jersey: Swets and Zeitlinger.

[31] Rogers, J. (1989). Adults Learning. Buckingham: Open University Press.

[32] Scovel, T. (1978). The Effect of Affect on Foreign Language Learning: A Review of Anxiety Research. Language Learning, $28(1), 129-142$

[33] Vanc1, O. Ü. (1996). Foreign Language Classroom Anxiety: How Can We Get Our Students to Participate More? International ELT Conference From Diversity to Synergy (pp. 1-19). Ankara: Ankara Üniversitesi.

Recep Gulmez was born in Erzurum, Turkey. He received his B.A. degree as French Language teaching from Ataturk University and completed his M.A. degree in applied linguistics at the Sorbonne-Nouvelle Paris 3 and continued his PhD studies at the same university from 2008 until 2011. His research interests include applied linguistics, teacher education, sociolinguistics. He is currently teaching at Erzincan University in Turkey. 